\title{
Short Communication: \\ Exploration of bidara laut (Strychnos lucida) parent trees in Gunung Tunak Ecotourism Park, West Nusa Tenggara, Indonesia
}

\author{
ALI SETYAYUDI, KRISNAWATI, RYKE NANDINI ${ }^{*}$ \\ Non-Timber Forest Product Technology Research and Development Institute. Jl. Dharma Bhakti No. 7, Ds. Langko, Lombok Barat, West Nusa \\ Tenggara, Indonesia. Tel./fax. +62-370-6175482,`email: rykenand@yahoo.com.
}

Manuscript received: 26 September 2018. Revision accepted: 31 December 2018.

\begin{abstract}
Setyayudi A, Krisnawati, Nandini R. 2019. Short Communication: Exploration of bidara laut (Strychnos lucida) parent trees in Gunung Tunak Ecotourism Park, West Nusa Tenggara, Indonesia. Biodiversitas 20: 374-378. Bidara laut (Strychnos lucida R. Brown) is one of the widely used medicinal plants. There is a bidara laut wood processing industry in West Nusa Tenggara that produces drinking cups called 'health cups' utilizing bidara laut. All raw materials used for the production of health cups are, however, obtained from bidara laut stands in forest areas, which may cause the extinction of this medicinal plant species if the highly intensive raw material harvesting in the forest is not supported with cultivation of this plant species. To preserve this plant species, the Institute for Research and Development of Non-Timber Forest Products Technology (NTFP-RDI) has carried out breeding activities by developing a collection garden of this species from the populations of Bali and West Nusa Tenggara (Lombok and Sumbawa Islands). The initial step carried out was the exploration of the parent trees followed by collection of generative materials (seeds) and nurseries. Exploration of bidara laut parent trees on Lombok Island was carried out in Gunung Tunak Ecotourism Park using a purposive sampling method, followed by collection of fruits to obtain seed propagating materials for establishment of seedling nurseries. Twenty-five parent trees were identified with average height of nine $\mathrm{m}$, stem diameter of $24 \mathrm{~cm}$ and stem straightness scales of 1-3. The average seed produced was 413 seeds tree ${ }^{-1}$. Three parent trees were selected based on the highest seed germination rates, namely parent trees number 6, 14 and 20. This result provides useful information for the next bidara laut breeding activities.
\end{abstract}

Keywords: Bidara laut, collection garden, Gunung Tunak Ecotourism Park, medicinal plant, parent tree, Strychnos lucida

\section{INTRODUCTION}

Bidara laut (Strychnos lucida R. Brown) is the one of the rare plants (Pribadi 2009) widely used by people in Bali and West Nusa Tenggara (NTB) as ingredients of traditional medicine. Almost all parts of bidara laut such as stems, leaves and fruit possess medicinal properties (Setiawan et al. 2014). This tree has been used as traditional medicinal treatments for malaria, stomach aches, nausea, toothache, high blood pressure, and fever (Wahyuni 2014). In Dompu, bidara laut wood, also known as songga wood, has been used for production of drinking glasses or bowls and health promoting powder used by brewing it with boiling water (Gusmailina and Komariyati 2015). According to Zuraida et al. (2012), bidara laut glass sales market is not only at the local level but also abroad such as in Malaysia, Singapore and Hong Kong.

Bidara laut has high economic value so that the exploitation of the tree is becoming more excessive in recent years. The problem faced is that the bidara laut raw materials are still solely harvested from the stands in the forest area, which could cause extinction if the bidara laut harvest is continuously intensive and excessive and not balanced with cultivation efforts. The availability of propagation material is an important aspect in bidara laut cultivation. Bidara laut can be propagated both vegetative and generatively. Constraint encountered in bidara laut vegetative propagation is that shoots and stem cuttings used as vegetative propagating materials are of low successful rate with sprouting percentage of $<40 \%$. In addition, the flowering season of this plant is sometimes not synchronous, causing difficulties in obtaining fruits and seeds as generative propagation materials (Nandini and Agustarini 2010; Rahayu and Riendriasari 2016; Krisnawati et al. 2017). One effort to preserve bidara laut from extinction is by tree breeding. According to Leksono and Widyatmoko (2010), tree breeding activities can be started by selecting a parent tree to obtain high-quality seeds. In parent tree selection, factors that need to be considered are above average growth rate and superior phenotype.

Exploration of parent trees is the initial step of breeding activity (Rayan and Cahyono 2012) which is carried out by collecting generative propagating material (fruits and seeds) from the selected parent trees (Haryjanto and Hadiyan 2014). Bidara laut population were found in West Bali forest area (Bali Island), Dompu-Bima forest area (Sumbawa Island), and Gunung Tunak Ecotourism Park (TWA) area in Lombok (Setiawan and Rostiwati (2014).

In 2015, the NTFP-RDI carried out an exploration of parent trees in the forest area of West Bali National Park. Six best parent trees were selected from 53 prospective parent trees based on height and diameter of the seedlings derived from collected seeds (Krisnawati et al. 2015). In 
2016, another exploration was carried out in Dompu and Bima forest areas, West Nusa Tenggara; seven prospective parent trees were found in flowering stage, and some of the flowers produced no seeds as they fell out when the rainy season came. Bidara laut trees are no longer found in many forest areas as the forest areas were altered to maize gardens (Krisnawat et al. 2016).

Following the parent tree exploration in Bali and Sumbawa Islands, the next activity was the exploration of parent trees in Gunung Tunak Ecotourism Park, Central Lombok. The aim of the study was to obtain parent trees as seed sources from Lombok Island. Afterwards, progeny tests will be further carried out to obtain the best parents whose seeds will be widely used as superior seeds to increase the production and sustainability of bidara laut.

\section{MATERIALS AND METHODS}

\section{Study area}

The research area was located at the south end of Lombok Island in Central Lombok District, West Nusa Tenggara Province, Indonesia., with an altitude of 0-150 m above sea level, an E-type climatic zone (Schmidt and Fergusson), and an average rainfall of around $916 \mathrm{~mm} /$ year (Natural Resource Conservation Center of the West Nusa Tenggara, 2016). Bidara Laut seedling nursery was established in the Forest Area for Special Purposes (FAWSP) of Rarung, NTFP-RDI in Pemepek Village, Pringgarata District, Central Lombok Regency, West Nusa Tenggara.

\section{Procedures}

Determination of parent trees

Exploration of parent trees was done purposively by considering the criteria of the parent tree referring to the regulation of the Director General of Land Rehabilitation and Social Forestry Number: P.05 / V-SET / 2010 concerning Guidelines for Implementation of Standard Seed Sources. Based on these guidelines, the number of parent trees is at least 25 trees with a minimum distance between parent trees of $100 \mathrm{~m}$ to obtain a fairly wide genetic variation. The initial survey was conducted on the existing bidara laut population to be assessed according to the criteria, ratings and values stated in the guidelines for implementing standard seed sources. Twenty five parent trees were selected based on the phenotype such as growth and fruit yield.

\section{Fruit collection}

Collection of fruit as generative propagating material was done by collecting physiologically ripened fruits from each parent tree. Each of the obtained fruits then was labeled with a unique number. The collected fruit was extracted or discarded to get seeds. The seeds were then washed and sundried for 1-2 days to allow they germinate more easily.

\section{Germination}

The dried seeds were germinated in a container using sterilized sand media. The seeds were pressed into the media and covered with a thin sand layer. Irrigation was done routinely using hand sprayer. Germination was observed for 3 months and the percent germination was calculated once a month. Germination percentage was calculated as proportion of the number of germinating seeds to the total number of seeds sown.

\section{Data analysis}

Obtained data on parent trees exploration and nursery activities were tabulated and analyzed descriptively.

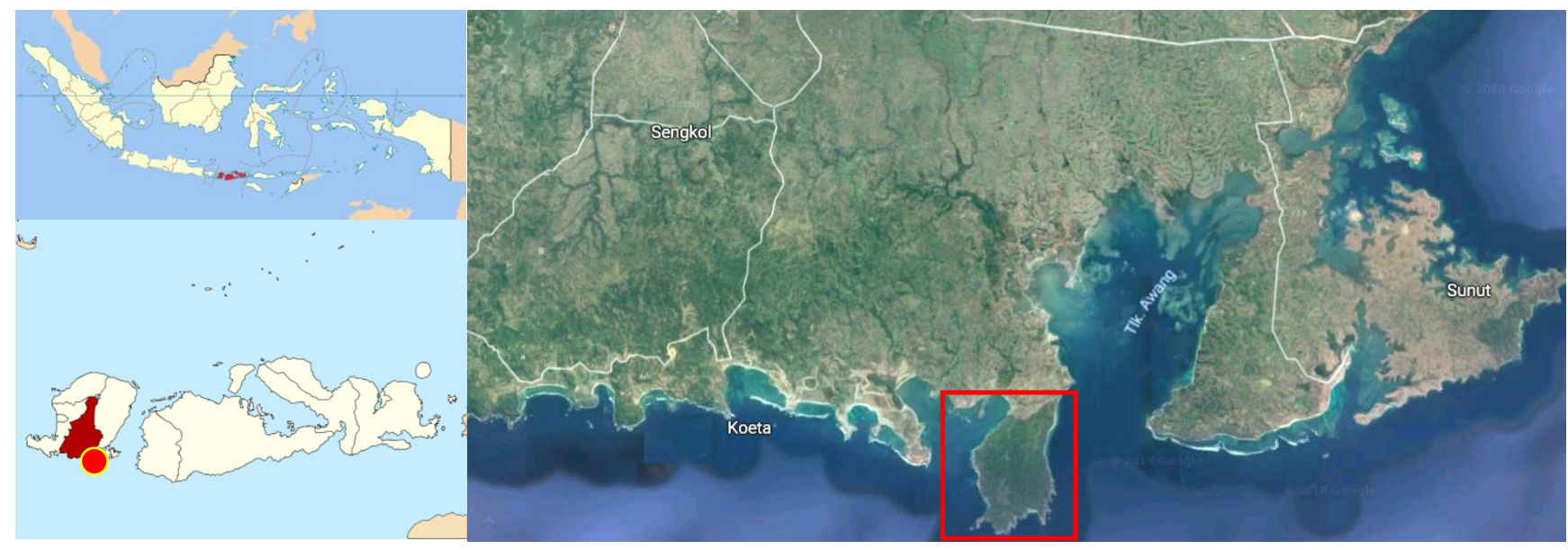

Figure 1. Study site in Gunung Tunak Ecotourism Park, Central Lombok District, West Nusa Tenggara Province, Indonesia 


\section{RESULTS AND DISCUSSION}

Preliminary survey at Gunung Tunak Ecotourism Park showed that the location of bidara laut was concentrated in the same forest area. However, the name of growing site was different, namely Bunut, Bagik Pondok, Rawa Bagik Pondok and Pantek. Bidara laut was found around the coast with an altitude of 62-109 $\mathrm{m}$ asl. This was almost the same as bidara laut growing sites in Dompu (Nandini 2011). The growing site of the bidara laut was quite dry, with an average humidity of $14 \%$ and air temperature of almost always above $30^{\circ} \mathrm{C}$ during daytime. In general, the growing sites of bidara laut have similar conditions because the sites are still located in one forest area around the coastal area. The biophysical conditions of the bidara laut growing sites are presented in Table 1.

During the present bidara laut exploration in Gunung Tunak Ecotourism Park forest area, twenty parent trees were selected; twelve of them were being fruiting. The characteristics of selected parent trees are presented in Table 2.

The twenty five parent trees had an average height of $8.4 \mathrm{~m}$, diameter of $19.5 \mathrm{~cm}$ and straightness stem index of 1-2. According to the Manual of Plus Tree Selection issued by the Javanese and Madura Forest Plants Seedling Center
(2006), the straightness stem index of 1-2 means that the stem is relatively bent. Bidara laut trees found in the field were not as good and as straight as trees in the general forest. Bidara laut stems were more bent and branch resembling shrubs; parent trees with straight stem were hardly found. However, the stem straightness is not an absolute factor for being a parent tree. There are other factors that can be used to determine a tree to become a parent tree; these factors include the number of fruit produced and the usable active compounds content.

In selecting fruiting parent trees, the selected trees are those with physiologically mature fruits. The physiologically mature fruits of bidara laut are usually characterized by the reddish yellow color they posses (Rahayu and Wahyuni 2013). Fruit collection can be done by direct harvesting of fruit or by picking up fruit fallen under the tree canopy. However, picking up fruit from around of the tree was not done to avoid mixing of the fruits from different parent trees. After the extraction process, 4961 seeds were obtained with an average number of seeds was 413 tree $^{-1}$. The germinated seeds were counted every months during three months based on number of sprouts emerged. Percent seed germination data at tree months after planting are shown in Figure 1.

Table 1. Biophysical conditions and characteristics of the parent tree of bidara laut growing in GunungTunak Ecotourism Park, West Nusa Tenggara, Indonesia

\begin{tabular}{|c|c|c|c|c|c|c|c|c|c|c|c|}
\hline \multirow{3}{*}{$\begin{array}{c}\text { Acc. } \\
\text { No. }\end{array}$} & \multirow{3}{*}{ Location } & \multicolumn{7}{|c|}{ Biophysical conditions } & \multicolumn{3}{|c|}{ Parent tree characteristics } \\
\hline & & \multirow{2}{*}{$\begin{array}{l}\text { Alt. } \\
\text { (m) }\end{array}$} & \multirow{2}{*}{ Topography } & \multirow{2}{*}{$\begin{array}{c}\text { Slope } \\
(\%)\end{array}$} & \multicolumn{2}{|c|}{ Temp. $\left({ }^{\circ} \mathrm{C}\right)$} & \multicolumn{2}{|c|}{ Humid. (\%) } & \multirow{2}{*}{$\begin{array}{c}\text { Height } \\
\text { (m) }\end{array}$} & \multirow{2}{*}{$\begin{array}{c}\text { Diameter } \\
(\mathbf{c m})\end{array}$} & \multirow{2}{*}{$\begin{array}{l}\text { Straightnes } \\
\text { of the stem }\end{array}$} \\
\hline & & & & & Soil & Air & Soil & Air & & & \\
\hline 1 & Bunut & 77 & Flat & 0 & 35 & 32 & 53 & 14 & 5 & 25 & 3 \\
\hline 2 & Bagik Pondok & 71 & Flat & 0 & 38 & 32 & 55 & 12 & 10 & 32 & 3 \\
\hline 3 & Bagik Pondok & 64 & Flat & 0 & 32.5 & 31 & 60 & 15 & 12 & 35 & 3 \\
\hline 4 & Bagik Pondok & 64 & Flat & 0 & 32.2 & 32.4 & 67 & 14 & 6 & 33 & 2 \\
\hline 5 & Bunut & 68 & Flat & 0 & 31.5 & 29 & 72 & 15 & 20 & 55 & 2 \\
\hline 6 & Rawa Bagik Pondok & 65 & Flat & 0 & 30.8 & 29.6 & 67 & 16 & 15 & 39 & 2 \\
\hline 7 & Rawa Bagik Pondok & 62 & Flat & 0 & 30.8 & 29.9 & 66 & 16 & 10 & 52 & 2 \\
\hline 8 & Rawa Bagik Pondok & 62 & Flat & 0 & 31.5 & 31.3 & 61 & 15 & 10 & 17 & 2 \\
\hline 9 & Rawa Bagik Pondok & 70 & Flat & 0 & 33.7 & 33 & 52 & 15 & 11 & 15 & 3 \\
\hline 10 & Rawa Bagik Pondok & 66 & Flat & 0 & 33.5 & 33.1 & 56 & 13 & 6 & 11 & 1 \\
\hline 11 & Rawa Bagik Pondok & 56 & Flat & 0 & 29.7 & 29.8 & 75 & 16 & 10 & 12 & 2 \\
\hline 12 & Rawa Bagik Pondok & 64 & Flat & 0 & 31.4 & 32 & 68 & 14 & 9 & 14 & 2 \\
\hline 13 & Rawa Bagik Pondok & 75 & Flat & 0 & 32.4 & 30.8 & 60 & 11 & 7.8 & 14.5 & 2 \\
\hline 14 & Rawa Bagik Pondok & 71 & Flat & 0 & 31.9 & 31.7 & 63 & 10 & 6.5 & 10 & 1 \\
\hline 15 & Rawa Bagik Pondok & 69 & Flat & 0 & 31 & 32 & 63 & 10 & 6 & 10 & 1 \\
\hline 16 & Pantek & 78 & Hilly & 21 & 30 & 29.4 & 84 & 16 & 4 & 6.5 & 2 \\
\hline 17 & Pantek & 83 & Hilly & 25 & 31.2 & 30.5 & 70 & 15 & 7 & 12.8 & 2 \\
\hline 18 & Pantek & 82 & Hilly & 40 & 33 & 31.4 & 65 & 15 & 8 & 14 & 2 \\
\hline 19 & Pantek & 86 & Hilly & 33 & 33.1 & 30.7 & 55 & 15 & 7.5 & 17 & 2 \\
\hline 20 & Pantek & 99 & Hilly & 24 & 32.2 & 30.4 & 60 & 15 & 8 & 15 & 1 \\
\hline 21 & Pantek & 109 & Hilly & 13 & 31.2 & 30.4 & 63 & 11 & 8 & 10.5 & 2 \\
\hline 22 & Pantek & 96 & Hilly & 8 & 29.9 & 29 & 63 & 11 & 8 & 10.5 & 2 \\
\hline 23 & Pantek & 96 & Hilly & 13 & 31 & 30.34 & 70 & 10 & 6 & 11.5 & 1 \\
\hline 24 & Pantek & 96 & Hilly & 24 & 31.7 & 31 & 60 & 10 & 6.8 & 9.5 & 2 \\
\hline 25 & Pantek & 96 & Hilly & 32 & 32.8 & 31.6 & 59 & 15 & 2.5 & 6 & 1 \\
\hline
\end{tabular}




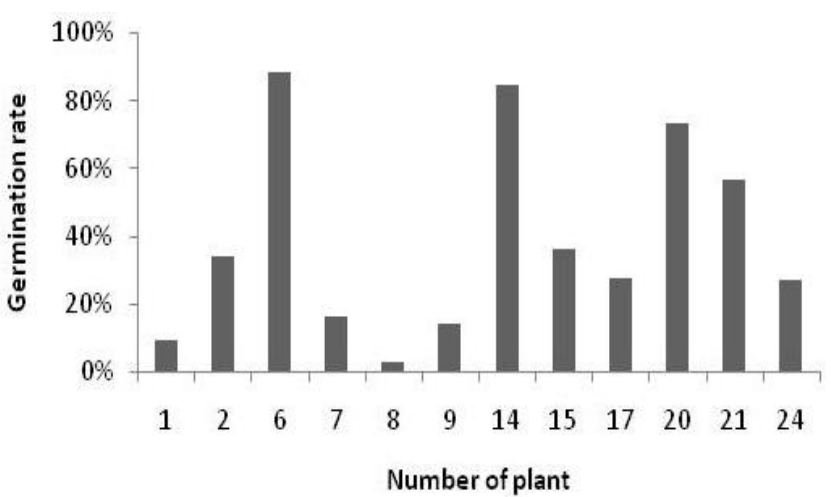

Figure 1. Germination rate of bidara laut plants in 3 months after planting

The results showed that the average seeds germination rate was $39 \%$ during three months observation period and $49 \%$ during five months observation period. The average percentage of seeds germination for three months was lower than that of five months. The germination rates of seeds of parent trees from Gunung Tunak Ecotourism Park were not substantially different from those of seeds of parent trees from Bali Island (39.62\%) (Krisnawati et al. 2015). Rahayu (2014) reported that germination rate of bidara laut seeds at three and a half months ranged from 48-59\%. There was only three tree that had a germination percentage above $70 \%$, i.e., The tree number 6,14 and 20 , while the lowest seed germination percentage $(<20 \%)$ was observed in four trees (tree number 1, 7, 8, and 9). This low seed germination rate was thought to be influenced by the optimal time limit for extracting the seeds. In general, seed drying carried out for one week can accelerate seed germination. Seed scarification treatment and proper seed extraction will accelerate seed germination and increase the percentage of sprouts (Baker 1950 and Suginingsih 1989 in Sandi et al. 2014).

Figure 2 shows that the increase of the seed germination of the twelve trees over the three months followed almost the same trend but the germination rate was higher in tree numbers 6, 14 and 20. At one month after seedling, almost all seeds germinated except those of tree number 1 . There was an increase in the seeds germination rate at two months after seeding. In the third month, there was no significant increase in the percentage of germination; a constant germination rate was observed except for tree numbers 21 and 6. Figure 2 shows that the second observation in the second month after seeding illustrated the overall germination percentage rates, with an average of $35 \%$. Parent tree number 14 experienced the fastest germinating rate (above $80 \%$ in the second observation), followed by three numbers 20 and 6 . Uniform growth and high germination rate indicate that seeds of these parent trees have good vigor (Yuniarti et al. 2016).

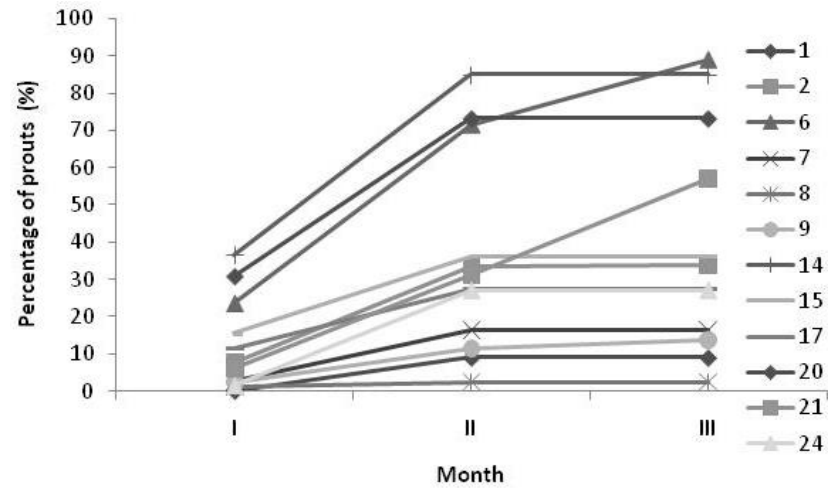

Figure 2. Percent accumulation of sprouts during 3 months of observation

Differences in germination rate are caused by many factors. Variations in the germination rate from each parent tree tend to be caused by both external and internal factors. External factors such as humidity and temperature in the FAWSP Rarung nursery were still the ideal range $(80.56 \%$ and $26.37^{\circ} \mathrm{C}$, respectively) to support germination process. According to Sutopo (2002), the optimum temperature and humidity for seed germination are, respectively, $26.5-35^{\circ} \mathrm{C}$ and $60-90 \%$. Temperature and humidity are very important factors in seed germination process, in addition to other external factors such as oxygen, light intensity, and the growing media (Irianto 2012). Thus, the low germination rate was not caused by external factors.

Internal factors influencing seed germination include, specifically, the seed quality. The seeds planted in the nursery might not be in good condition to germinate as they might have been physically and physiologically disrupted and damaged. This condition might have caused a decrease in germination rate and the seedling viability. This can be one of the factors that lowered the germination rate. In addition, Bidara laut seeds take a long time to germinate. Our observations during the study showed that the seeds started to germinate at an average of almost eight weeks after sowing. According to Suita and Bustomi (2014), the seeds appertain hard to grow if they don't germinate in more than a week after sowing. The hard seed structure is another likely factor that caused the longer time required for germination to take place and the low germination rate of bidara laut seeds as reported in the present study. Seeds with hard structure can hinder gas exchange and imbibitions of water, thereby inhibiting germination (Siregar 2014). The average germination rate of 39\% for three months is considered low, which necessitates appropriate scarification technique to increase the germination rate. Information on parent tree with a high seed germination rate is important to support for tree breeding activities. 


\section{ACKNOWLEDGEMENTS}

The authors would like to thank Gipi Samawandana and Ramdiawan who helped take samples in the field; and the Gunung Tunak Ecotourism Park staff who have assisted in the exploration of bidara laut.

\section{REFERENCES}

Gusmailina, Komariyati S. 2015. Exploration of the potential of organic snakewood (Strychnos lucida) as a Biopharmaca. Pros Sem Nas Masy Biodiv Indon 1 (7): 1741-174. [Indonesian]

Haryjanto L, Hadiyan Y. 2014. Seed exploration of Nyawai (Ficus variegata Blume) at Long Hubung, West Kutai District, East Kalimantan. Wana Benih 15 (2): 61-72. [Indonesian]

Irianto. 2012. Germination and growth phenology of Duku seedlings (Lansium domesticum Corr.). Jurnal Pertanian 1 (4): 23-31.

Krisnawati, Hendarto KA, Rahayu AAD, Prihantini AI, Samawandana G. 2016. Ecology and Pranajiwa Germination Technique in Lombok; Shoot cuttings Propagation Techniques and Exploration of Provenan bidara laut (Strychnos lucida) on Sumbawa. NTFP Technology Research and Development Institute, Mataram. [Indonesian]

Krisnawati, Hendarto KA, Setiawan O, Nugraheni YA, Rahayu AAD, Samawandana G. 2015. Increased Productivity of Pranajiwa (Euchresta horsfieldii) and bidara laut (Strychnos lucida) NTFPs as a Potential Source of Potential Medicines in Bali and West Nusa Tenggara. NTFP Technology Research and Development Institute, Mataram. [Indonesian]

Krisnawati, Setyayudi A, Prihantini A, Samawandana G, Ramdiawan. 2017. Trial Planting of Pranajiwa (Euchresta horsfieldii) Type of Medicinal Plants and Sea Spray (Strychnos lucida) and Its Activity and Toxicity Test. NTFP Technology Research and Development Institute, Mataram. [Indonesian]

Leksono B, Widyatmoko A. 2010. Breeding strategy for biofuel raw materials. In Proceedings of the National Seminar on Science and Technology III: The Strategic Role of Science and Technology in Achieving National Independence. Forestry Research and Development Agency. Ministry of Forestry, Bandar Lampung. [Indonesian].

Nandini R. 2011. Study of environmental aspects of bidara laut Sites (Strychnos lucida R.Br) in Dompu District, West Nusa Tenggara. In: Proceeding the Exposure of Makassar Research Institute: R, D results to support Sustainability and Forest Use. Conservation and Rehabilitation Research and Development Center, Bogor. [Indonesian].

Nandini R, Agustarini R. 2010. Generative cultivation technique of bidara laut (Strychnos lucida R.Br.). In: Synthesis of Plantation Forest Research Results. Forestry Research and Development Agency, Bogor. [Indonesian]

Natural Resource Conservation Center of the West Nusa Tenggara. 2016 Long-Term Management Plan for Gunung Tunak Ecotourism Park in Central Lombok Regency, West Nusa Tenggara Province 2016 to 2025. Directorate General of Natural Resource Conservation and
Ecosystems, Ministry of Environment and Forestry, Mataram. [Indonesian].

Pribadi E. 2009. Supply and demand for Indonesian medicinal plant and the direction of their research and development [Indonesian]. Perspektif 8 (1): 52-64. [Indonesian].

Rahayu AAD. 2014. Bidara laut Nursery (Strychnos ligustrina Blume. syn. S. lucida R. Br. In: Rostiwati T, Setio P (eds.). Bidara laut (Strychnos ligustrina Blume) syn. S. lucida R. Br: Source of Potential Medicinal Materials in West Nusa Tenggara and Bali. Forda Press, Bogor. [Indonesian]

Rahayu AAD, Riendriasari SD. 2016. The influence of some regulating substances growing on the growth of bidara laut stem cuttings (Strychnos ligustrina). Jurnal Perbenihan Tanaman Hutan 4 (1): 25 31.

Rahayu AAD, Wahyuni N. 2013. Generative and Vegetative Breeding Techniques for Biadar Laut/Songga. NTFP Technology Research and Development Institute, Mataram. [Indonesian]

Rayan, Cahyono DDN. 2012. Exploration of genetic material collection Shorea leprosula Miq. for basic populations and breeding populations. Info Teknis Dipterokarpa 5 (1): 35-45.

Sandi AL. I Indriyanto, Duryat. 2014. Seed size and scarification with hot water against duku tree seed germination (Pericopsis mooniana). Jurnal Sylva Lestari 2: 83-92.

Setiawan O, Wahyuni N, Susila WW, et al.. 2014. Bidara laut (Strychnos ligustrina Blume) syn. S. lucida R. Br. In: Rostiwati T, Setio P (eds.). Bidara laut (Strychnos ligustrina Blume) syn. S. lucida R. Br: Source of Potential Medicinal Materials in West Nusa Tenggara and Bali. Forda Press, Bogor. [Indonesian]

Setiawan O, Rostiwati T. 2014. Bidara laut (Strychnos ligustrina Blume. Syn. S. lucida R. Br): Potential NTFPs in NTB and Bali. In: Rostiwati T, Setio P (eds.). Bidara laut (Strychnos ligustrina Blume) syn. S. lucida R. Br: Source of Potential Medicinal Materials in West Nusa Tenggara and Bali. Forda Press, Bogor. [Indonesian]

Siregar BL. 2014. The germination and dormancy breaking of andaliman (Zanthoxylum acanthopodium DC.) seed. J Agron Indonesia 41 (3): 249-254. [Indonesian]

Suita E, Bustomi S. 2014. Technique of increasing power and speed of germination of pilang seeds. Jurnal Penelitian Hutan Tanaman 11 (1): 45-52.

Sutopo L. 2002. Seeds Technology. Raja Grafindo Perkasa, Jakarta [Indonesian].

Wahyuni N. 2014. Ethnobotany of the bidara laut (Strychnos ligustrina Blume. Syn. S. lucida R. Br) in West Nusa Tenggara and Bali. In: Rostiwati T, Setio P (eds.). Bidara laut (Strychnos ligustrina Blume) syn. S. lucida R. Br: Source of Potential Medicinal Materials in West Nusa Tenggara and Bali. Forda Press, Bogor. [Indonesian]

Yuniarti N, Zanzibar M, Megawati M, Leksono B. 2016. Vigority of Acacia crassicarpa A. Cunn. ex Benth. seeds from several sources. Jurnal Penelitian Hutan Tanaman 13 (2): 123-131. [Indonesian]

Zuraida, Sukito A, Darmawan S. 2012. Conservation and protection of songga tree (Strychnos lucida R Brown) as rare and valuable tree species. A case study in Sumbawa Island- Indonesia. In: Sim HeokChoh LM, Abdul Hamid S (eds.). Asia and the Pacific Workshop Multinational and Transboundary Conservation of Valuable and Endangered Forest Tree Species. IUFRO Headquarters, Vienna, Austria. 